\author{
Lukasz Michalski \\ Uniwersytet Śląski \\ w Katowicach
}

\title{
Filozofia narracji historycznopedagogicznej Bogdana Nawroczyńskiego
}

\author{
[...] iść w chaos i czynić zeń \\ kosmos. \\ Bogdan Nawroczyński ${ }^{1}$
}

Pedagogika odchodzi od swego intelektualnego charakteru i ,nie chce lub nie potrafi generować idei" - stwierdza Aleksander Nalaskowski². Często spłaszczane kontekstowo i nerwowo ,szprycowane" modnymi tematami kultury popularnej teorie pedagogiczne nie tworzą dobrego podłoża do przezwyciężenia tego impasu. Bywa, że nie stanowią go także teorie głębokie - odpowiedzialne - bowiem, aby stały się ideą, muszą kumulować w sobie ładunek emocjonalny. Deficyt tej energii sprawia, że teorie „mogą wiele wyjaśnić, ale niczego nie potrafią zmienić"3. Idee opierają się zmienności, rysują "granice historyczności”, dlatego z samej swej natury zdają się być widoczne przede wszystkim w perspektywie dziejowej. Zasadne zatem wydaje się upatrywanie źródeł wskazanego kryzysu także w słabości perspektywy historycznopedagogicznej ${ }^{5}$. Pomijanie, deprecjonowanie lub - co gorsza - pozytywistyczna brutalizacja metodologiczna refleksji historycznej w pedagogice prowadzi do rozłącznego traktowania dziejów i teorii

${ }^{1}$ B. Nawroczyński, Życie duchowe. Zarys filozofii kultury, Kraków-Warszawa 1947, s. 13.

${ }^{2}$ A. Nalaskowski, Pedagogiczne złudzenia, zmyślenia, fikcje, Kraków 2009, s. 7.

${ }^{3}$ Tamże, s. 8.

${ }^{4}$ B. Skarga, Granice historyczności, Warszawa 1989.

${ }^{5} \mathrm{O}$ niedocenionym czy też źle obecnym potencjale perspektywy historycznej pisze Lech Witkowski: „Paradoksalnie, jak przekonują losy historii myśli filozoficznej, wielcy duchem, »niewspółobecni« nam czasowo i przestrzennie, bywają bardziej nowocześni i przynoszący większą możliwość czynienia transparentnym świata, którego istnienia nie mogli przecież nawet przewidywać, niż niejeden z naszych współobecnych tu i teraz uczonych i badaczy, traktowanych czasem zupełnie niesłusznie, jako naturalnie dziedziczący wielkość minioną i wnoszących do niej swój udział" (L. Witkowski, O pamięć teoretyczna myśli pedagogicznej, [w:] tegoż, Ku integralności edukacji i humanistyki II, Toruń 2009, s. 169). 
wychowania. Efektem tego jest także podział pracy akademickiej na hermetyczne obszary „historyków” i ,teoretyków”, który prowadzi do źle pojętego bezpieczeństwa w ramach własnego pola badań i umożliwia zrzeczenie się odpowiedzialności za namysł nad wychowaniem „w ogóle”. Tymczasem gra o status i metodologiczną jakość narracji historycznopedagogicznej jest grą o przyzwoitość standardów samej pedagogiki. Stawka jest wysoka, a przestroga Szeherezady aż nazbyt czytelna: król zabija, gdy brak jest opowieści ${ }^{6}$.

Wkład Bogdana Nawroczyńskiego w rozwój polskiej myśli pedagogicznej jest zwykle osadzany w kontekście pedagogiki kultury. Przede wszystkim podkreśla się zatem wagę pisanej podczas II wojny światowej książki Życie duchowe. Zarys filozofii kultury ${ }^{7}$ - chyba najważniejszego dzieła uczonego. Jednakże ważnym elementem jego dorobku jest także wydana w roku 1938 Polska myśl pedagogiczna ${ }^{8}$, w której autor daje się poznać jako świetny historyk myśli. Książka ta $\mathrm{z}$ jednej strony rzadko bywa obiektem analiz, z drugiej zaś - jeśli już takowe są czynione - przedstawiana jest jako tekst ważny, ba, wręcz dla perspektywy historycznej w pedagogice przełomowy ${ }^{9}$. Ponadto, wagę syntezy Nawroczyńskiego oddaje także recepcja jego dzieła, gdyż - jak zauważa Władysława Szulakiewicz Polska myśl pedagogiczna często pełniła (nadal pełni) funkcję podręcznika, mimo że z uwagi na cechy gatunkowe de facto podręcznikiem nie jest ${ }^{10}$. W moim zaś przekonaniu książka Bogdana Nawroczyńskiego jest modelowym podręcznikiem, którego wysoka wartość płynie - paradoksalnie - z faktu, że jest to projekt nieudany. Warto zatem w perspektywie namysłu nad kształtem współczesnych strategii narracji historycznopedagogicznej pochylić się nad wspomnianym dziełem ${ }^{11}$.

\footnotetext{
${ }^{6} \mathrm{~W}$ Baśniach tysiąca i jednej nocy król Szachrijar po nocy poślubnej zabija każdą nowo poślubioną żonę w obawie przed jej ewentualną niewiernością. Jedna z nich - księżniczka Szeherezada - opowiada mu jednak baśń, którą nad ranem pozostawia bez zakończenia. Z samej ciekawości władca pozostawia księżniczkę przy życiu. Ta zaś odtąd co noc stosuje ten sam fortel. Szeherezada by przeżyć, nie może przerwać swej opowieści.

${ }^{7}$ B. Nawroczyński, Życie duchowe...

${ }^{8}$ B. Nawroczyński, Polska myśl pedagogiczna. Jej główne linie rozwojowe, stan współczesny i cechy charakterystyczne, Lwów-Warszawa 1938.

${ }^{9}$ T. Hejnicka-Bezwińska, Konsekwencje a-historyczności pedagogiki, [w:] Pedagogika ogólna. Tradycja - teraźniejszość - nowe wyzwania, red. T. Hejnicka-Bezwińska, Bydgoszcz 1995; S. Sztobryn, Polskie badania nad myśla pedagogiczna w latach 1900-1939. Ujęcie metahistoryczne, Łódź 2000.

${ }^{10} \mathrm{~W}$. Szulakiewicz, Podręczniki historii wychowania jako źródto historyczne ,, adresowane”, [w:] Źródta w badaniach naukowych historii edukacji, red. W. Szulakiewicz, Toruń 2003, s. 122.

11 „Cichą" (bo jedynie tu wzmiankowaną) metodologię niniejszych rozważań stanowią przede wszystkim dwa koherentne podejścia badawcze: koncepcja struktury tekstu Barbary Skargi (cztery warstwy: problematyka tekstu wraz ze „sposobami jej rozwiązania”, warstwa
} 
Nawroczyński już na samym początku książki imponuje świadomością narracji. Metatekstowe komentarze, samoodniesienia i czynienie przedmiotem namysłu także samego procesu konstruowania narracji historycznej należą do najjaśniejszych punktów dzieła. Tekst Polska myśl pedagogiczna. Jej główne linie rozwojowe, stan wspótczesny i cechy charakterystyczne - bo tak brzmi jego pełny tytuł - rozpoczyna autor od krótkiej Przedmowy, którą w głównej mierze stanowią podziękowania za pomoc podczas pracy nad książką. Nie sposób nie wspomnieć, iż Nawroczyński przyznaje się tu do zaciągnięcia długu wdzięczności wobec takich postaci, jak Stanisław Kot, Helena Radlińska i Sergiusz Hessen, wskazując tym samym na rodowód wielu swych narracyjnych decyzji. Po wspomnianej krótkiej przedmowie następuje nieco obszerniejszy Wstęp, gdzie dochodzi do zarysowania projektu, którego książka ma być realizacją. Zachodzi tu doprecyzowanie ujętych $\mathrm{w}$ tytule książki kategorii. Wskazuje zatem badacz na dwojakie pochodzenie poglądów wytwarzanych przez narody $\mathrm{w}$ teoriach pedagogicznych: zewnętrzne (idee mające obieg światowy, które naród „,przemyślał”) oraz wewnętrzne (swoiste dla narodu, zrealizowanie ,po swojemu najwyższych ideałów kultury"12), rysując jednocześnie dwie optyki, które wykorzystuje już we właściwym przedstawieniu myśli pedagogicznej. Idzie zatem o to, by zbadać, jak tło światowych tendencji korespondowało z rozważaniami o polskim rodowodzie; ale także - a może nawet przede wszystkim - o to, co wniosła polska myśl pedagogiczna do refleksji powszechnej ${ }^{13}$.

kategorialno-pojęciowa, reguły sensu, a także horyzont ontologiczny - epistema) oraz metoda metahistoryczna w ujęciu Sławomira Sztobryna (por. B. Skarga, Granice historyczności...; S. Sztobryn, Polskie badania nad myśla pedagogiczna...).

${ }^{12}$ B. Nawroczyński, Polska myśl pedagogiczna ..., s. 5.

${ }^{13}$ Zauważmy, jak rzadkie są podobne spojrzenia we współczesnym konstruowaniu polskich teorii pedagogicznych, gdzie szuka się przede wszystkim pokrycia z tendencjami światowymi (wpływu tychże) albo luk w rodzimym dorobku, które zagraniczna twórczość może wypełnić. Współczesna polska myśl pedagogiczna zadaje się często być merytorycznie defensywna. Dlatego też warto choć w pobieżnym przypisie wskazać niektóre elementy wyznaczające specyfikę polskiej myśli pedagogicznej na tle rozważań światowych, które wyróżnia na podstawie swych analiz Nawroczyński:

- praktycznie nastawiona umysłowość polska owocuje konkretnym i praktycznym charakterem idei;

- pedagogika polska odznaczała się zawsze bardzo wyraźnym nastawieniem socjalnym;

- system wychowania obywatelsko-państwowego (A. F. Modrzewski, S. Konarski, KEN) znacząco różni się od ogólnych trendów oświeconego absolutyzmu czy systemu platońskiego - nie jest narzucony ,z góry”, lecz wyrastał „,z dołu”;

- centralne dla polskiej myśli pedagogicznej pojęcie narodu jest owocem polskiej wolności politycznej, efektem zespojenia najrozmaitszych elementów etnicznych - to wolność budowała samowiedzę narodową;

- „W Polsce wieją wiatry przeważnie z zachodu. I w dziejach polskiej myśli pedagogicznej panował w ciągu stuleci ciągle wiatr zachodni” - wpływów wschodnich nie można traktować 
Jeśli już w tym miejscu, ze względu na nie tylko narodowy, ale i światowy kontekst rozważań, można w zamiarach Nawroczyńskiego odnaleźć znamiona projektu trudnego, podobne wrażenie wzmaga przyjęta przez autora definicja polskiej myśli pedagogicznej. Rozumie ją pisarz jako „wszystko to, co stanowi godną uwagi treść naszej literatury pedagogicznej, a więc nie tylko teorie pedagogiczne o charakterze bardziej lub mniej naukowym, lecz również publicystykę pedagogiczną"14. Ponadto, narracja rozgrywa się zarówno stricte w obszarze idei, jak i wyzyskuje kontekst dziejów szkolnictwa i podłoże kulturowe ${ }^{15}$.

Obok tak ujętego horyzontu rozważań przedstawia autor również strategię wertykalną, chodzi bowiem o odszukanie głębszego sensu teorii pedagogicznych i ich struktury. „Głębokość” spojrzenia na materiał historyczny określa wskazanie cezur czasowych, które jednocześnie są kolejnymi poziomami nasycenia narracji. W ten sposób powstają jej trzy plany - to, co dawne (rozdz. I), bliższe (rozdz. II) i współczesne (rozdz. III-V) - gdzie pierwszy opisany jest krótko i na najwyższym poziomie ogólności, ostatni zaś, najszerszy, obfituje w detale i dogłębne analizy. Nawroczyński wskazuje tu dość dokładne daty graniczne ${ }^{16}$. Centrum zaś wszystkich tych rozważań - czyli jednocześnie ich cel i punkt wyjścia - stanowi teraźniejszość: „Zrozumieć współczesną naszą twórczość pedagogiczną w jej związku z twórczością poprzednich pokoleń - oto zadanie" ${ }^{17}$. Nawroczyński sięga

jako determinujących czy charakterystycznych dla polskiej myśli pedagogicznej (B. Nawroczyński, Polska myśl pedagogiczna..., s. 274);

- polska myśl pedagogiczna, w konsekwencji późnego wejścia w krąg kultury łacińskiej, wciąż musi doganiać zachodnich sąsiadów; jest też myślą „różnych prędkości” (o znacznym zróżnicowaniu dynamiki rozwoju), chociaż „im dalej posuwamy się naprzód, tym krótsze są okresy zastoju, tym dłuższe okresy wytężonego życia duchowego" (tamże, s. 276-277);

- na gruncie polskim myśl pedagogiczna była zawsze stosunkowo zaawansowana - jedynie w okresie romantyzmu ,wyprzedziła” ją literatura piękna i filozofia; tym niemniej, była w stanie podnieść cały naród z upadku, odrodzić moralnie, przygotować do poniesienia największych ofiar i poświęcenia (tamże, s. 278-279);

- specyficzna dla polskiej myśli pedagogicznej jest także synteza idealizmu romantycznego z pozytywistycznym realizmem.

${ }^{14}$ Tamże, s. 9. Wykształcony filologicznie Nawroczyński szuka myśli pedagogicznej także w literaturze, która „tak często wyprzedza rzeczywistość” (tamże, s. 293).

${ }^{15}$ Co świetnie uzasadnia Nawroczyński stwierdzając, iż idee bez kontekstu są jak ryba bez wody - można je „krajać lancetem analizy”, lecz podobna sekcja ,już w nich nie znajdzie tego życia wewnętrznego, w które można by się wczuć, aby je jeszcze i w ten sposób zrozumieć" (tamże, s. 16).

${ }^{16}$ Stąd też następująca struktura rozdziałów:

- Rozwój polskiej myśli pedagogicznej do roku 1863 [począwszy od wieku XVI - przyp. Ł. M.],

- Pedagogika pozytywna (1863-1886),

- Pedagogika wzmożenia duchowego (1886-1914),

- Ideały pedagogiczne Polski odrodzonej (1914-1935),

- Rozwój nauk pedagogicznych.

${ }^{17}$ B. Nawroczyński, Polska myśl pedagogiczna ..., s. 9. 
po dzieje myśli nie w przypływie archiwistycznej pasji katalogowania, lecz w poszukiwaniu odpowiedzi na pytania wywołane specyfiką własnych czasów. Stąd teraźniejszość jest w narracji historycznej punktem wyjścia i dojścia jednocześnie.

Na problematyczność tak zarysowanego zadania przede wszystkim składa się nieredukowalna trudność opisu czasów badaczowi współczesnych. W wypadku Nawroczyńskiego nie jest to tylko „standardowe” uwikłanie w przedmiot zainteresowania, gdzie nikły dystans czasowy ciąży ku silnemu zsubiektywizowaniu narracji. Kwestię obiektywności odwzorowania dodatkowo komplikuje dotkliwy brak tematycznie przystających monografii, którymi ewentualnie Nawroczyński mógłby się posiłkować oraz konieczność pisania o własnym wkładzie w myśl pedagogiczną. Jest zatem Nawroczyński niezwykle uważny - wręcz podejrzliwy - wobec obecności autora w narracji; bywa, że w książce wyraźnie kim innym jest Nawroczyński - teoretyk pedagogiki, a kim innym Nawroczyński - historyk myśli pedagogicznej. W tym miejscu rozważań, wskazując na kłopotliwe narracyjnie konteksty - nie tylko specyficzne dla dzieła, ale i charakteryzujące ogólną naturę spisywania dziejów myśli - uczony wydaje się daleki od naiwnego przekonania o transparentności tekstowego przekazu oraz lekceważenia retorycznego uwikłania konstruowanej opowieści, co zapewne w znacznej mierze jest owocem studiów filologicznych i prawniczych autora. W efekcie już na samym wstępie rozważań pojawia się wyznanie, iż Polska myśl pedagogiczna będzie pracą „daleką od doskonałości"18. Zauważmy jednak, że na gruncie wcześniejszych analiz metatekstowych twierdzenie to raczej nie skłania do poczucia, że mamy tu do czynienia z nieudolnością autora; prędzej z projektem, którego niedopełnienie jest równocześnie jego integralnym założeniem ${ }^{19}$.

W omawianym Wstępie Nawroczyński swoje wątpliwości co do możliwości obiektywnego odzwierciedlenia myśli pedagogicznej ujmuje w następujących słowach:

W tych warunkach napisana książka musi być daleka od doskonałości. Nie wyczerpie ona tematu, nie wyjaśni wielu szczegółów, nie uwolni się, być może, całkowicie od pewnego subiektywizmu $^{20}$.

${ }^{18}$ Tamże, s. 15.

${ }^{19}$ De facto każda próba spisania syntezy historycznej kończy się fiaskiem, okazuje się bowiem, iż „zarzut niekompletności zasobu >danych empirycznych< $<$ służących formułowaniu i eksplikacji tez można postawić zawsze" (K. Kasztenna, Z dziejów formy niemożliwej. Wybrane problemy historii i poetyki polskiej powojennej syntezy historycznoliterackiej, Wrocław 1995). Niniejszy cytat pochodzi ze świetnej książki polskiej badaczki narracji historycznoliterackiej, ale równie dobrze można by przywołać tu tezy Izajasza Berlina, Haydena White’a czy Rolanda Barthesa - także współczesnego Nawroczyńskiemu Marca Blocha. Skojarzenia z twórczością ostatniej z wymienionych postaci wywołuje także przedmowa do Życia duchowego (B. Nawroczyński, Życie duchowe...).

${ }^{20}$ B. Nawroczyński, Polska myśl pedagogiczna ..., s. 15. 
Zwróćmy uwagę na owo „być może”, które zdaje się dopuszczać możliwość całkowitego uwolnienia się od skrzywienia narracji swoistością indywidulanej perspektywy autora. Warto pamiętać, że w twórczości Nawroczyńskiego dość wyraźne jest charakterystyczne dla początków przełomu antypozytywistycznego dążenie do tego, by metodologia nauk humanistycznych była równie „godna szacunku jak ta, którą dysponowały nauki przyrodnicze"21. Słusznie zauważa Krzysztof Maliszewski:

W polskiej pedagogice kultury o żywotności niektórych aspektów pozytywizmu najmocniej chyba świadczy twórczość Bogdana Nawroczyńskiego. Jako wychowanek Kazimierza Twardowskiego, cenił ścisłość i nie miał zaufania do metafizyki ${ }^{22}$.

Tendencję tę widać także w obiektywizujących zabiegach narracyjnych. Wskazywana już w niniejszych rozważaniach głęboka świadomość narracji autora Polskiej myśli pedagogicznej jawi się z tej perspektywy jako efekt dążenia do możliwie pełnego zidentyfikowania zagrażających jej obiektywizmowi zakłóceń. Stąd szeroka charakterystyka materiału i precyzyjny podział tematyczny treści, stabilnie osadzone w uzasadnieniach cezury czasowe, kontekst rozważań pisarzy zagranicznych czy próba wypracowania dystansu wobec własnej twórczości. Źródłem tej postawy jest także dość często obecna w tekście retoryczna „nuda”; Nawroczyński - w którego bogatym wachlarzu studiów tkwi także filologia polska - dążąc do językowej neutralności ${ }^{23}$, hamuje wybujałość słów, która tylko w niektórych momentach wyziera spod przyjętego „twardego” dyskursu.

Można mieć jednak poważne wątpliwości, czy wszystkie te obwarowania nie pozostawiły obiektywności tekstu jedynie w randze roszczenia. Nietrudno zauważyć, że bieg narracji Nawroczyńskiego wyznacza przede wszystkim jedna kategoria - naród ${ }^{24}$. Historyczne wątki dziejów myśli pedagogicznej wplata autor

${ }^{21}$ P. Ricoeur, Zadanie hermeneutyki, [w:] tegoż, Język, tekst, interpretacji, Warszawa 1989, s. 198.

${ }^{22} \mathrm{~K}$. Maliszewski, Teoria wychowania moralnego w pedagogice kultury II Rzeczypospolitej, Katowice 2004, s. 32-33.

${ }^{23}$ Jak twierdzi Izajasz Berlin, bliscy osiągnięcia neutralności swego języka są ewentualnie statystycy, socjologowie, ekonomiści czy pracownicy wywiadu (I. Berlin, Cztery eseje o wolności, Poznań 2000).

${ }^{24} \mathrm{O}$ narracji Nawroczyńskiego należałoby zatem mówić jak o spojrzeniu „skrzywionym” (,zakrzywionym”) - używając dość „wytartego” zwrotu anglosaskiej teorii historiografii, zamiast strategii to get the story straight mamy do czynienia ze strategią to get the story crooked. Naród byłby zatem owym zakrzywiającym analizy pryzmatem. Trzeba jednak pamiętać, że w ostatnich słowach Zakończenia omawianej książki także sam Bogdan Nawroczyński formułuje swój „wzór”, który mógłby stanowić dominantę podjętych rozważań: „Człowiek - Naród - Państwo” (B. Nawroczyński, Polska myśl pedagogiczna..., s. 293). Na podstawie zawartego w Polskiej myśli pedagogicznej rozumienia wspomnianych trzech kategorii, można sprowadzić je do innej jeszcze postaci: kultura - myśl pedagogiczna - oświata. Przez pryzmat kultury postrzegany jest bowiem człowiek, od myśli pedagogicznej zależna jest kondycja narodu, głównie w perspektywie oświaty 
w intrygę ${ }^{25}$ zawiązaną wokół dążenia narodu polskiego do odzyskania niepodległości. W opowieści Nawroczyńskiego nie ma pustych miejsc czy niepotrzebnych bohaterów. Autor nie oddaje przestrzeni postaciom, którym nie ma zamiaru poświęcić większej uwagi - ba, nawet ich nie wspomina - raz zaś obsadzona rola jest znacząca i pojawia się często także we fragmentach, które nie są jej poświęcone ${ }^{26}$. Nawet tendencje przeciwstawne lub znacznie różniące się od narodowych, zdają się służyć odzyskaniu niepodległości. Sejmikowy „warchoł polityczny” jest antytypem wywołującym ,dzielnego i prawego patriotę”27; pozytywistów polskich wywodzi Nawroczyński z postaw romantycznych i opisuje z perspektywy celów narodowych ${ }^{28}$; także poglądy Heleny Radlińskiej sprowadza autor do perspektywy narodowej kosztem społecznego charakteru jej twórczości.

Oczywiście nie mamy tu do czynienia z grą wypaczeń i przekłamań, lecz daleko idąca spójność faktów i przedstawianych poglądów sugeruje ich celowy dobór czy też jednostronną perspektywę ich odczytania, tym bardziej że w omawianym tekście dzieje myśli pedagogicznej układają się w klasyczny schemat fabularny. Wspomniane już trzy plany narracji wyznaczają okresy upadku, walki i zwycięstwa. Schemat ów za swoisty dla konstruowania intrygi uznaje także za Arystotelesem Ricoeur:

Właściwą normą wielkości (horos) intrygi jest taka jej długość, która - poprzez kolejny bieg zdarzeń - pozwala na zasadzie prawdopodobieństwa lub konieczności na przemianę [losu bohatera] ze szczęścia w nieszczęście bądź z nieszczęścia w szczęście ${ }^{29}$.

Jeśli jednak cały tekst wydaje się wpisywać w tę konstrukcyjną dominantę, to jej realizacja najwięcej trudności przysporzyła Nawroczyńskiemu - paradoksalnie - w rozdziałach poświęconych narodowemu nurtowi w polskiej myśli pedagogicznej. W wypadku pozostałych nurtów autor rzeczywiście zachowuje dość znaczną neutralność języka - co najwyżej przedstawiając z odcieniem sympatii pedagogikę społeczną czy już z pewnym zaangażowaniem kwestie emancypacji kobiet. Gdy opowieść skupia się bezpośrednio na przedstawicielach pedagogiki nurtu narodowego, autor pozwala sobie na tony metafizyczne i retoryczną wybuja-

opisywane jest zaś państwo. Tym niemniej, w książce Nawroczyńskiego nadal najsilniejszą „grawitacją" zdaje się cechować kategoria narodu.

${ }^{25}$ Intryga w odczytanym przez Ricoeura ujęciu arystotelesowskim - rozumiana zatem jako zgodność; jedność celów i przyczyn, łączność epizodów, spójność czasu i domknięcie akcji (P. Ricoeur, Czas i opowieść, t. 1, Intryga i historyczna opowieść, Kraków 2008).

${ }^{26}$ Przede wszystkim można by tu wskazać „pierwszoplanowego” Lucjana Zarzeckiego, ale także Stanisława Szczepanowskiego, Helenę Radlińską czy Stanisława Konarskiego.

${ }^{27}$ B. Nawroczyński, Polska myśl pedagogiczna..., s. 285.

${ }^{28}$ To, że owe cele nie są aż tak wyraźne w pismach pozytywistów, wskazywać ma jedynie na ograniczenia cenzury.

${ }^{29}$ P. Ricoeur, Czas i opowieść..., s. 65. 
łość. Bogdan Nawroczyński chce zatem „wejrzeć w głąb duszy”30 przyrównanego do Mojżesza ${ }^{31}$ Stanisława Szczepanowskiego, którego myśl była ,jakby powiewem wolnego wiatru, odświeżającym duszną atmosferę niewoli, jakby wołaniem orła, dochodzącym spod krat więziennych"32.

Podobnej „,euforii” opisu nie ma jednak w wypadku omówienia tez Zygmunta Balickiego - przedstawiciela poglądów często radykalnie nacjonalistycznych i raczej niespójnych. Nawroczyński zresztą stwierdza, że żadnej ze wspomnianych postaci nie można uznać za teoretyka pedagogiki narodowej. Może zatem nieco dziwić poświęcenie im w Polskiej myśli pedagogicznej... stosunkowo długich opisów. Natomiast pełnoprawnym teoretykiem nurtu jest wedle autora Lucjan Zarzecki. Jeśli zatem szukać kluczowej postaci w opowieści Nawroczyńskiego, to w konsekwencji niniejszych rozważań winien nią być właśnie Zarzecki. I rzeczywiście, to chyba postać najczęściej w książce cytowana, wielokrotnie „wplatana” w kolejne rozważania. Jednakże, gdy dochodzi do przybliżania samych poglądów pedagoga, okazuje się, że w oczach Nawroczyńskiego Zarzecki był „naturą namiętną, nierówną, umysł miał nieco chaotyczny"33; pedagog, który usystematyzował nurt narodowy w swej twórczości „nigdy dobrze związanej i dokładnie opracowanej większej całości nie stworzył"34, czego powodem była zapewne znaczna mozaikowość inspiracji (J. F. Herbart, pedagodzy kultury, W. Stern, wychowanie angielskie, amerykańska literatura pedagogiczna). Chaotyczność przedmiotu opisu - twórczości Zarzeckiego - zdaje się udzielać także Nawroczyńskiemu ${ }^{35}$.

Dziwić może także wyodrębnienie kolejnego podrozdziału - po Pedagogice narodowej następuje część zatytułowana Pedagogika życia duchowego. Jednakże poza wspomnianymi już Balickim, Szczepanowskim i Zarzeckim, pojawia się tu np. Wincenty Lutosławski (postać, jak zaznacza sam Nawroczyński, której

\footnotetext{
${ }^{30}$ B. Nawroczyński, Polska myśl pedagogiczna..., s. 128.

${ }^{31}$ Tamże, s. 136.

${ }^{32}$ Tamże, s. 137.

${ }^{33}$ Tamże, s. 143.

${ }^{34}$ Tamże, s. 143-144.
}

${ }^{35}$ Zaczyna ujawniać dotąd skrywany głos autorski - padają zwroty: „moim zdaniem”, „nie mam zamiaru" (tamże, s. 145) czy też zapowiedzi strategii dalszych części tekstu, których autor nie realizuje. Zapowiada, że nie będzie się odnosił do wspólnych dla myśli Zarzeckiego i twórczości Balickiego oraz Szczepanowskiego zagadnień, by ukazać to, co było dla Zarzeckiego swoiste. Okazuje się jednak, że nie tylko takie odwołania się pojawiają, ale wspominane postacie stanowią główne tło rozważań. Nawroczyński mozolnie „przepracowuje” te treści na dziewięciu niełatwych stronach. W dalszych już częściach książki dość trudne do „przełknięcia” dla czytelnika mogą okazać się także momenty, w których Nawroczyński komentuje własną twórczość. Dochodzi nawet do przedziwnego spotkania na przestrzeni kilku zdań Nawroczyńskiego - autora Polskiej myśli pedagogicznej... z Nawroczyńskim - twórcą tejże myśli (tamże, s. 206). Ponadto, ujmując swój głos w narrację trzecioosobową autor zmuszony jest jednocześnie do równoprawnego traktowania przedstawicieli opcji go krytykujących czy przyznania im większego wpływu na ustawodawstwo - czyli wskazania na własne słabości bądź nawet błędy. 
filozofia nie zyskała uznania ${ }^{36}$ ); opisany zostaje także Stanisław Brzozowski (poeta, filozof, krytyk literacki, którego mało kto rozumiał, choć miał wielu wielbicieli), „nowy”, mistyczny Jan Władysław Dawid, a w tle Stanisław Witkiewicz i Adam Mickiewicz. Zatem trudno oprzeć się wrażeniu, że nadal mowa jest o pedagogice narodowej, a Nawroczyński wydzielając pedagogikę życia duchowego dynamizuje przemiany myśli pedagogicznej nieco sztucznie. Być może chodzi o odcięcie się drogą wyznaczenia nowego nurtu od radykalnego nacjonalizmu niektórych „narodowców” czy nieudanych prób wyzwoleńczych. Ostatecznie jednak Nawroczyński „przyciągnął” Zarzeckiego do spójnego Szczepanowskiego, jednocześnie negując radykalny nacjonalizm Balickiego. Ponadto, sprowadzając kosztem perspektywy społecznej twórczość Heleny Radlińskiej do dominującej perspektywy narodowej i zarysowując w kolejnym rozdziale wydarzenia rewolucji szkolnej, Nawroczyński przygotował polską myśl pedagogiczną do pełnienia funkcji źródła odzyskanej niepodległości.

Fabularny schemat intrygi jest także skutecznie „ratowany” w końcowych częściach książki ${ }^{37}$. Wszak odzyskanie niepodległość jest wypełnieniem się fabuły, podczas gdy piszący swą książkę u schyłku lat 30. wieku XX Nawroczyński nie urywa dziejów myśli na roku 1918. Wewnętrzną zgodność i ciągłość fabuły - a tym samym także intrygi - udaje się jednak w znacznej mierze utrzymać i w narracji dotyczącej Polski niepodległej. Po pierwsze dlatego, że - jak zresztą słusznie wskazuje uczony - data 11 listopada 1918 r. nie stanowi w dziejach kultury duchowej przełomowej granicy, a pedagogika po I wojnie światowej „nazbyt jeszcze wiązana jest z czasami przedwojennymi, aby można było zrozumieć jej myśl pedagogiczną bez sięgnięcia w tę przeszłość" 38 - zatem łączność przedwojennej i powojennej myśli pedagogicznej podtrzymuje spójność narracji. Po drugie, Nawroczyński zaczyna przenosić ciężar głównej dominanty analiz z kategorii narodu na kategorię państwa. Dążenia narodowowyzwoleńcze zastąpione zostają dążeniami wyznaczanymi ,ideałem mocy państwowej, wywyższonym ponad wszystko przez marszałka Józefa Piłsudskiego" ${ }^{39}$. Stąd podtrzymany zostaje motyw walki o kondycję narodu, tym razem już związanego z państwowością. Niemniej jednak trzeba przyznać, że ostatnia część książki nie nosi już znamion tak daleko idącej spójność, jaką widzimy w rozdziałach wcześniejszych. W opisie Polski niepodległej narracja „rozszczepia się”, ze strony na stronę coraz większy staje się udział w tekście wyliczeń i opisów praktyki wychowawczej, form

${ }^{36}$ Tamże, s. 154.

${ }^{37}$ Spójność narracji została poddana poważnej próbie także wobec konieczności opisu czasu rozbiorów, które przez separację terytorialną automatycznie prowadziły do zróżnicowania trendów w myśli pedagogicznej, a tym samym atomizacji prowadzonej narracji. Ta ostatnia jednak nie zachodzi. Nawroczyński wskazuje, że rozwój myśli i dążeń Polaków łączy spójna kategoria narodu oraz podkreśla nadrzędną (przewodnią) rolę Galicji (polski Piemont).

${ }^{38}$ B. Nawroczyński, Polska myśl pedagogiczna..., s. 12.

${ }^{39}$ Tamże, s. 292. 
oświaty pozaszkolnej, charakterystyka metod nauczania czy wzajemnej relacji państwo-szkoła.

Jeśli zatem układanie intrygi to „wydobywanie na jaw zrozumiałego z przypadkowego, uniwersalnego z pojedynczego, koniecznego lub prawdopodobnego z epizodycznego" "40, to Nawroczyński rzeczywiście, wchodząc w chaos, czyni zeń kosmos. Formułując podobną tezę w swojej próbie uchwycenia natury narracji historycznej, Izajasz Berlin zdaje się łączyć Nawroczyńskiego z odczytanym przez Ricoeura Arystotelesem w następujących słowach:

Przedstawić historyczne wyjaśnienie, to nie tylko opisać następstwo zdarzeń, lecz uczynić je zrozumiałymi; a uczynić zrozumiałymi, $[\ldots]$ to odsłonić podstawowy wzór, nie jeden z kilku możliwych wzorów, ale jeden, niepowtarzalny plan, który przez to, że jest taki, a nie inny, służy tylko jednemu szczególnemu celowi i dlatego jawi się jako włączony w swoisty sposób do jednego, „kosmicznego", wszechogarniającego schematu, stanowiącego cel wszechświata, za którego sprawą jest on w ogóle wszechświatem, a nie chaosem nie powiązanych części i elementów ${ }^{41}$.

$* * *$

Wspomniany udział opisów oświaty w treści Polskiej myśli pedagogicznej... zwiększa się wraz ze zbliżaniem się do czasów autorowi teraźniejszych i myślę, że podobna tendencja jest charakterystyczna w historiografii wychowania: im przedmiot opisu jest bliżej współczesności, tym bardziej narracja „ześlizguje się” z dziejów myśli pedagogicznej ku historii oświaty. Jest to zapewne konsekwencją dostępu do materiałów dokumentujących przeszłość - im jest ona bliższa, tym większe jest nasycenie źródeł. Stąd jakościowe przeobrażanie się narracji z jednolub kilkulinowej, skupionej głównie na teoretycznych analizach (myśl pedagogiczna) w narrację mozaikową, będącą raczej faktograficznym odwzorowaniem (historia oświaty). Schemat ten przywołuje jednak także na myśl mechanizm działania ludzkiej pamięci, gdzie to, co współczesne, zdaje się złożone i wymaga czasowego oddalenia, by stało się spójne i zdeterminowane. Filozofia narracji historycznopedagogicznej Bogdana Nawroczyńskiego - pomimo obiektywizujących nadziei autora - umiejscawia się po stronie pamięci (sensu, rozumienia, to get the story crooked), a nie historii (poznania, wyjaśnienia, to get the story straight) ${ }^{42}$.

${ }^{40}$ P. Ricoeur, Czas i opowieść..., s. 68.

${ }^{41}$ I. Berlin, Cztery eseje..., s. 116.

${ }^{42}$ Racja jest czymś innym niż sens. Pierwsza sprowadza się do poznania, drugi zaś do rozumienia. Ratio ujawnia się w decyzjach autora tekstu, wymaga precyzji pojęć, eliminacji niedookreśloności i wieloznaczności, domaga się logiki wywodu i poddania go krytycznej ocenie rozumu - uzasadnienie jest tu zawsze traktowane jako postulat naczelny, lecz, jak twierdzi Skarga, dziś już „nie przypuszczamy, aby można było ustalić rację z pewnością absolutną” (B. Skarga: Granice historyczności..., s. 169), dlatego odwołać się należy do szerszej kategorii sensu, której reguły opierają się na powiązaniu z emocjami, wyobrażeniami, obrazami, metaforami; „, [...] sens odsłania się, racja wyjaśnia, dlaczego coś jest tym, czym jest, sens się wypełnia, rację się ustala, sens się tworzy, choć nie bywa dowolny, ale jest przed nami, w przyszłości; racja jako podstawa czasu nie zna, sens 
Neguje także pozorną rozłączność perspektywy synchronicznej i diachronicznej, historia jest bowiem pisana „znikąd” - z epistemologicznie niezawisłego dystansu - natomiast pamięta się zawsze „skądś”, wszak ta sama przeszłość wypełniała się różnymi znaczeniami w zależności od teraźniejszości, w której się wspomina. Michał Paweł Markowski, czytając list Konstantego Aleksandra Jeleńskiego do Józefa Czapskiego o książce Sartre’a poświęconej Flaubertowi (sic!), stwierdza:

prześwietlenie rzeczywistości sprzeciwia się pamięci. Pamiętamy jedynie to, co nieprześwietlone, nieprzezroczyste, co stawia opór naszemu umysłowi. Nieprzejrzystość istnienia jest warunkiem jego przetrwania: to, co uzyskuje całkowitą przejrzystość, nie może przetrwać, a więc nie może być pamiętane ${ }^{43}$.

Wydaje się zatem, że widoczna - nieprzezroczysta - narracja Nawroczyńskiego, której nie udało się uczynić obiektywizującym spojrzeniem „na wskroś", pozwala myśli przetrwać. Jeśli wskazuje się na dziwną żywotność jego (nie)podręcznika, to moim zdaniem takie oto są jej przyczyny.

Mówienie o życiu i śmierci refleksji w dziejach myśli pedagogicznej nie jest poetycką grą metafor, lecz realnym zagrożeniem. Zauważmy, że dwudziestowieczne perypetie pedagogiki opierają się na przynajmniej dwóch dyskwalifikacjach czy też wyparciach: nurtów międzywojennych przez pedagogikę socjalistyczną oraz tej ostatniej przez pedagogikę współczesną ${ }^{44}$. W konsekwencji wypierane nurty funkcjonują zredukowane do „suchej” wiedzy archiwalnej lub na zasadzie przerwy w pamięci pedagogiki ${ }^{45}$, co prowadzi do czysto mechanicznego ,używania" podręcznikowych postaci z historii wychowania, faktograficznej ,żonglerki” i wywoływania pozoru kontekstowego zakotwiczenia ${ }^{46}$. Stąd Polska myśl pedagogiczna... Bogdana Nawroczyńskiego wydaje się niezwykle

jest otwarty i wiąże się z wartościami, rację chciałoby się ująć w czystym rozumowaniu nie zanieczyszczonym tym, czego udowodnić się nie da. Być może właśnie te cechy racjonalnego myślenia uczyniły z niego zasadę zasad, uzurpującą sobie prawo do ważności absolutnej, jedynego gwaranta wiedzy prawdziwej, to jest nauki, podczas gdy tam, gdzie chodzi o sens, wkraczają jako pełnoprawne: religia, poezja, historia, ba, nawet metafizyka" (tamże, s. 170-171).

${ }^{43}$ M. P. Markowski, Jeleński: rzeczywistość prześwietlona, [w:] tegoż, Życie na miarę literatury, Kraków 2009, s. 345. Oto rzeczony passus z Jeleńskiego: „rozczarowanie, mimo wielkiej, zawsze równie olśniewającej inteligencji, [która] strona po stronie prześwietla rzeczywistość, niczego nie dając, co by zostało w pamięci" (tamże).

${ }^{44}$ Ł. Michalski, Bogdana Suchodolskiego metahistoria wychowania. Szkic do analizy $w$ duchu koncepcji historii niekonwencjonalnej, [w:] Filozofia wychowania w XX wieku, red. S. Sztobryn, E. Łatacz, J. Bochomulska, Łódź 2010.

${ }^{45}$ Kategorię ,przerwanej pamięci pedagogiki” sformułował także w jednym ze swych konferencyjnych wystąpień Zbigniew Kwieciński, wskazując na przykłady takich „,przerw”, wymienia m. in. dorobek Bogdana Nawroczyńskiego i Kazimierza Sośnickiego.

${ }^{46}$ Zresztą historyczne niekoniecznie oznacza wartościowe - pozytywny stosunek do badań nad przeszłością nie może przekładać się na pozytywny stosunek do przedmiotu tychże badań w sposób automatyczny. 
cennym wyznacznikiem standardów współczesnej narracji historycznopedagogicznej.

Dzieło to wydaje się także przykładem dzieła podważającego definitywny podział przedmiotu historii wychowania, który sformułował tuż po II wojnie światowej Bogdan Suchodolski ${ }^{47}$. Ten ostateczny, bo obowiązujący w niemal niezmienionej postaci, podział zakłada następujące elementy: dzieje doktryn i prądów pedagogicznych (domena pedagogów), dzieje szkół i instytucji oświatowo-wychowawczych (obszar badań historyków) oraz dzieje kultury (przestrzeń wspólnych zainteresowań pedagogów i historyków). Ponadto, tak zarysowaną panoramę poszerzyć należy o koncepcję Sławomira Sztobryna, który uzupełnia propozycję Suchodolskiego o dzieje historiografii pedagogicznej, czyli o element metahistoryczny ${ }^{48}$. Zauważmy jednak, że Bogdan Nawroczyński w swojej niespełna trzystustronicowej książce nie przestrzega wytyczonych w ten sposób granic. Jest historykiem idei, ale opisuje także dzieje oświaty oraz jej podłoże kulturowe ${ }^{49}$. Jeśli zaś przez perspektywę metahistoryczną rozumieć

typ badań naukowych, syntetycznych, odwołujących się do pola epistemologicznego, tj. holistycznego ujęcia zobiektywizowanej twórczości grupy intelektualistów badających w wyznaczonym czasie i przestrzeni (tj. w ramach przyjętych cezur) określone idee, stanowiska, kierunki i prądy myśli pedagogicznej oraz jej dzieje ${ }^{50}$,

to trudno odmówić Nawroczyńskiemu także takiej strategii ${ }^{51}$. Ponadto, historycznopedagogiczna narracja Polskiej myśli pedagogicznej... cechuje się

${ }^{47}$ Idzie tu przede wszystkim o tekst: B. Suchodolski, Stosunek pedagogiki do historii wychowania, [w:] Pamiętnik VII Powszechnego Zjazdu Historyków Polskich we Wrocławiu 19-22 września 1948, t. 2 z. 1, Warszawa 1948 (por. także B. Suchodolski, O nowy typ historii wychowania, „Nowa Szkoła” 1948, nr 4), chociaż podkreślić należy, iż podobne tezy pojawiały się w niektórych środowiskach historyków wychowania jeszcze w czasach międzywojennych (por. Historia oświaty i wychowania w Polsce 1918-1939, Toruń 2000; W. Szulakiewicz, Historia oświaty $i$ wychowania w Polsce 1944-1956, Kraków 2006; Ł. Michalski, Bogdana Suchodolskiego metahistoria wychowania...).

${ }^{48}$ Polskie badania nad myśla pedagogiczna w latach 1900-1939. Parerga, red. S. Sztobryn, Gdańsk 2006, s. 17; S. Sztobryn, Historia wychowania, [w:] Pedagogika, red. B. Śliwerski, t. 1, Gdańsk 2006, s. 2.

${ }^{49}$ Przywołać by tu trzeba raz jeszcze słowa z autorskiego Wstępu do Polskiej myśli pedagogicznej..., gdzie ukazana zostaje krytyczna rola oświatowego i kulturowego kontekstu (por. przyp. 15).

${ }^{50}$ S. Sztobryn, Polskie badania nad myśla pedagogiczna w latach 1900-1939. Ujęcie metahistoryczne..., s. 16-17.

${ }^{51}$ Tym bardziej że był już w niniejszym tekście wykazywany charakter synchroniczno-diachroniczny Polskiej myśli pedagogicznej ... oraz organizująca dzieło Nawroczyńskiego chęć uchwycenia w dziejach myśli tego, „,o jest względnie trwałym czy uniwersalnym wspólnym mianownikiem" - są także cechy dystynktywne podejścia metahistorycznego (S. Sztobryn, Historiografia edukacyjna i jej metodologia. Wybrane zagadnienia, [w:] Podstawy metodologii badań w pedagogice, red. S. Palka, Gdańsk 2010, s. 303). 
znaczącym udziałem wątków politycznych. Dlatego też warto zastanowić się, czy przykład dzieła Nawroczyńskiego nie skłania do reinterpretacji statusu przytoczonego tu wewnętrznego podziału historii wychowania. Czy nie stanowi on przede wszystkim cennego zarysowania horyzontu odpowiedzialności naukowej historyków wychowania, chroniąc przed popełnianiem krytycznych pominięć, kontekstowej redukcji i czy nie powinien stać się podstawą hermetycznej parcelacji dyscypliny $?^{52}$

${ }^{52} \mathrm{O}$ znaczeniu Nawroczyńskiego dla dyscyplinarnego statusu historii wychowania (dziejów myśli pedagogicznej, ale także historii oświaty) można myśleć w niemal identycznych słowach jak te, których użył niegdyś Paul de Man, tłumacząc źródła sporego znaczenia Waltera Benjamina czy Michaiła Bachtina dla literaturoznawstwa: „Teoria literatury, szczególnie zaś teoria narracji, to dziedzina raczej nieurodzajna, której uprawianiu nieustannie zagraża nuda technik i ogrom zagadnień, przez które trzeba przebrnąć; oferuje ona jałową glebę bohaterom, których kultu desperacko potrzebuje" (P. de Man, Dialog i dialogiczność, [w:] Ja-Inny. Wokót Bachtina - antologia, t. 2, red. D. Ulicka, Kraków 2009, s. 409). Wydaje się, że uprawianie historii wychowania zdradza podobne cechy w większym jeszcze natężeniu - stąd potrzeba „bohaterów” jest także bardziej paląca. W poszukiwaniu modelowych historyków wychowania - „Bachtinów” polskiej narracji historyczno-pedagogicznej - nie można przejść obojętnie obok takich postaci, jak Bogdan Suchodolski, Ludwik Chmaj, Bogdan Nawroczyński; zapewne także Sergiusz Hessen czy Bronisław Ferdynand Trentowski. 